\title{
Transparency in the Assessment of Takaful Claims for Construction Works Loss \& Damage
}

\author{
Puteri Nur Farah Naadia Mohd Fauzi (Corresponding author) \\ Department of Quantity Surveying, Kulliyyah of Architecture \& Environmental Design, \\ International Islamic University Malaysia (IIUM), 53100 Kuala Lumpur, Malaysia \\ Tel: 03-61966204/+6014-9311639 E-mail: puteri@iium.edu.my \\ Khairuddin Abdul Rashid \\ Department of Quantity Surveying, Kulliyyah of Architecture \& Environmental Design, \\ International Islamic University Malaysia (IIUM), 53100 Kuala Lumpur, Malaysia \\ Tel: +603-61965221 E-mail: khairuddin@iium.edu.my
}

\begin{abstract}
In the context of the construction industry, an alternative to the conventional insurance for works contracts is the Shariah compliant insurance otherwise known as takaful. Among the most frequently used takaful for construction works contracts is the Contractor's All Risks (CAR) Takaful. However, the future of CAR Takaful may be affected should issues such as marketing and clarification on how it works including how claims are processed, valued and compensation made are not made know to Contractors and Clients. In fact, previous studies have identified that issues on transparency in CAR Takaful products is among the major concerns expressed by the Contractors and Clients. Consequently, a study was conducted, the key objectives being to establish understanding on the concept of transparency in CAR Takaful claims and assess, from the perspectives of the Contractors and Clients, on whether the dealings in CAR Takaful claims are considered transparent or otherwise. The study was conducted principally via desk research and interviews with representative from takaful operators, Contractors and Clients organizations. Key results from the study suggest that transparency in CAR Takaful dealings is a concern especially those related to compliance with the Shariah and manner in which claims are valued and compensation decided. Such lack of transparency, if not addressed soonest possible, may not augur well for the future of
\end{abstract}

the CAR Takaful industry.

Keywords: construction, claims, compensation, transparency, takaful

\section{Introduction}

Islam highly encourages people to take full precautions and safety measures to protect and care for lives as well as properties in which this concept is based on a hadith of Prophet Muhammad (p.b.u.h) narrated by Al-Tirmizi and Ibn Majah, Book 60, No. 2517:

"The Prophet (p.b.u.h) noticed a Bedouin's camel and he asked the Bedouin, "Why don't you tie down your camel?" The Bedouin answered, "I put my trust in Allah". The Prophet said, "Tie your camel first, then put your trust in Allah".

It has been contended that the Shariah only allows risks to be managed through a form of insurance based on the concept of risksharing. The concept is referred to as a mutual agreement to assist and protect each other in the same group where each of the participants is required to contribute a sum of money, which is called a donation, and is entitled to relinquish claims on the amount if none of the unexpected events occur (Rodziah Ahmad \& Zairol Azhar Auzzir, 2012; Zuriah Abdul Rahman \& Hendon Redzuan, 2009). The concept of risk-sharing as a protection system is applied through a takaful 
- Shariah compliant insurance that has been set as a counter part of conventional insurance as stated by the Islamic Financial Services Board (IFSB) \& International Association of Insurance Supervisors (IAIS) (2006) "Takaful is the Islamic counter part of conventional insurance, and exists in both life (or "family") and general forms...".

The protection of properties under construction is sought through a Contractor All Risks (CAR) Takaful scheme offered by the takaful operators to Contractors and Clients to insure their works (Ahmad Mazlan Zulkifli et. al., 2012; Syed Othman Alhabshi et. al., 2012). The CAR Takaful policies are designed to provide cover against loss and damage to works and temporary works, materials, plants and other things brought onto site by the contractor and liability for property damages and bodily injury to third parties occurring in connection with a building and contract works (Ahmad Mazlan Zulkifli et. al., 2012). Since takaful is a Shariah compliance insurance, hence, its theoritical and practical operations must be fully adhere with the basic principles, concepts, understandings and requirements of the Shariah. Unfortunately, the practice in assessing takaful claims for construction works loss and damage seems to be lack of transparency and deficiency in terms of disclosure of materials and conduct (Puteri Nur Farah Naadia Mohd Fauzi \& Khairuddin Abdul Rashid, 2014; Mohd Fadzli Yusof et. al., 2011).

There is dearth of literature on the issue about transparency in CAR Takaful. Consequently, a study was conducted, the key objectives being to establish understanding on the concept of transparency in CAR Takaful claims and assess, from the perspectives of the Contractors and Clients, on whether the dealings in CAR Takaful claims are considered transparent or otherwise. This paper is structured into i) part 1 introduces the paper, ii) part 2 and 3 reviews relevant literature related to transparency and Car Takaful and the methodology employed in carrying out the study respectively, part 4 presents the results followed by discussion and finally part 5 provides a conclusion and recommendation to the paper.

\section{Objectives}

i) To establish understanding on the concept of transparency in CAR Takaful claims, and

ii) To assess, from the perspectives of the Contractors and Clients, on whether the dealings in CAR Takaful claims are considered transparent or otherwise.

\section{Transparency}

Transparency is defined as a concept of decisions and enforcement in which the information is adequately provided, understandable and freely and directly available and accessible to the affected group by such decision and their enforcement (Transparency Accountability Initiative, 2014; Sturges, 2007). The Transparency International: The Global Coaliation Against Corruption (2014) states that: "Transparency is a characteristic of governments, companies, organizations and individuals that are open in the clear disclosure of information, rules, processess and actions." Transparency is part of a strategy used for and by group of people to have the means, resources and opportunities to influence decision-making and affect development outcomes (Transparency Accountability Initiative, 2014). Transparency is expected to provide balancing between the openess of processes, performance and decisionmaking with the secrecy and protection of intellectual advantages and strategic planning (Doug Macamara \& Banff Executive Leadership Inc., 2014).

However, the Transparency Accountability Initiative (2014) emphasized that opacity could be created in stead of transparency by simply making large number of information available and accessible. Despite, information should not only be made available and accessible but also should be managed and published so that sufficient and reliable information are provided which lead to adequate transparency. The 
followings are the characteristics of information listed by the Transparency Accountability Initiative (2014) in order to ensure adequate transparency is performed:

i. Information must be relevant and accessible: Clear presentation and readily comprehensive, simple and understandable language and formats are appropriate. Information are to be made available in appropriate ways depending on the targetted group of people.

ii. Information must be timely and accurate: Should be made available in sufficient time, for example, from planning stage until implementation of the systems, to permit evaluation for decision-making and create engagement by relevant group of people. To ensure accuracy, information are required to be managed, hence, it shall be completed, updated and improved from time to time to suits the targeted group of people and outcomes of the implementation of the systems.

\section{Transparency in Islam}

According to Ahmad Sekreter (2013) predictability and confidence in islamic finance and business transactions should be as transparent as possible. The application of transparency in business dealings and trasactions shall be the core principle of good governance and accountability of the institutions and processes that involve decision-making (Mikaliu \& Maishanu, 2014; Muhammad Shabbir, 2010; Parigi, Geeta, \& Kailasam, 2004). In the Qur'an, among the key verses that relate to the need for transparency in the al-mua'malat are:

"...Nothing have we omitted from the book..." (Al-Quran, 6:38)

"Verily, this is My Way, leading straight: follow it: follow not (other) paths: they will scatter you about from His (great) path: thus does He command you, that you may be righteous."(AlQuran, 6:153)
The concept of transparency is asserted in the Qur'an and hadith through the demands of fair, open and ethical behavior in all business transactions. 'Abdullah Yusuf 'Ali (2000) has translated the Qur'an verses that requires business transactions be made through witnessed and written contracts.

"Oye who believe! When ye deal with each other, in transactions involving future obligations in a fixed period of time, reduce them to writing, let a scribe write down faithfully as between the parties: let not the scribe refuse to write: as God has taught him, so let him write. Let him who incurs the liability dictate, but let him fear his Lord God, and do not diminish ought of what he owes. If the party liable is mentally deficient, or weak, or unable himself to dictate, let his guardian dictate faithfully, and two witnesses, out of your own men, and if there are not two men, then a man and two women, such as ye choose, for witnesses, so that if one of them errs, the other can remind her. The witnesses should not refuse when they are called on (for evidence). Disdain not to reduce to writing (your contract) for a future period, whether it be small or big: it is juster in the sight of God, most suitable as evidence, and more convenient to prevent doubts among yourselves, there is no blame on you if ye reduce it not to writing. But take witness whenever ye make a commercial contract; and let neither scribe nor witness suffer harm. If ye do (such harm), it would be wickedness in you. So fear God; for it is God that teaches you. And God is well acquainted with all things." (A1-Quran, 2:282)

Transparency including honesty in business transactions is the hallmarks of Muslims identity and dealings. This is supported by numerous verses of the Qur'an that exhort believers to fulfill their contracts faithfully and testify honestly. Allah the Almighty states in the Qur'an:

"That is most suitable: that they may give the evidence in its true nature and shape, or else they would fear that other oaths would be taken 
after their oaths. But fear God, and listen (to His counsel): for God guideth not a rebellious people." (Al-Quran:108)

"And cover not Truth with falsehood, nor conceal the Truth when ye know (what it is)." (A1-Quran2:42)

In addition, Prophet Muhammad (p.b.u.h) also emphasis on the disclosure of a business transaction based on a hadith:

Hakim b. Hazim (Allah be pleased with him) reported Allah's Messenger (may peace be upon him) as saying: Both parties in a business transaction have the right to annul it so long as they have not separated; and if they speak the truth and make everything clear they will be blessed in their transaction; but if they tell a lie and conceal anything the blessing on their transaction will be blotted out (Sahih Muslim, Book No. 10: The Book of Transactions (Kitab Al-Buyu'), Hadith No. 3661).

\section{Transparency in Construction and Takaful}

In construction, the concept of transparency is applied through the application of documents required in pre and post contract stages. The application of contract document for construction works influence efficient method of construction contract management where by sufficient information are provided that indicate clearly and details in terms of specifications, drawings, legal requirements, materials, prices, cost and progress of works (Flynn, 2014). The transparent documents required and used in construction contracts has, to an extent, reduced the opportunity of disputes and for quick settlements with minimal supporting evidence (Flynn, 2014).The preparation and application of Bill of Quantities (BQ) during the tendering stage; later to be binded as contract document are intentoanally to promote transparency and disclosure of costs in which materials, parts and labour and all related costs are itemized. BQ includes all costs and is transparent in relations to all costs that covers all aspect of work, i.e. materials, labours, and any cost related aspects supplied by the contractor from inception to completion of the construction works (Flynn, 2014). Flynn (2014) stressed that BQ impairs transparency in regard to construction works costs in which it provides oppurtunity for creating a smoke screen around the contractor's original intentions. Thus, front end loading may go undetected, and new rates may be negotiated almost from scratch. Indeed, BQ is set as device to improve trust between parties in construction. BQ is designed to provide extensive construction information in terms of quantities, worksmanship, items, costs and specifications so it shall promote transparency (Jaggar, Ross, Love, \& Smith, 2001).

In addition, greater transparency in public sector construction project shall promote ethical values in the way by helping to reduce potential corruption. Transparency that refers to disclosure of information to the public in construction projects would help to reduce corruption by means of any activities that includes bribery, extortion, fraud, deception and collusion (UK Anti-Corruption Forum, 2008). The concept of transparency in public sector construction projects includes the disclosure of public information on public sector construction projects and therefore, be responsibility of project owner to ensure that disclosure is provided to the public by providing specified information in the condition of contract to the project participants (UK Anti-Corruption Forum, 2008).

As the Shariah encourages people to protect their lives as well as property from any risks, hence the application of takaful as a protection and indemnification scheme based on the concept of risk-sharing is permissible (Department of Islamic Development Malaysia (JAKIM), 1972). The Islamic Financial Services Act (IFSA) (2013) highlights on the requirements of standards business conduct that may embrace the standard application of transparency and disclosure requirements including the provision of information to financial consumers that is 
accurate, clear, timely and not misleading.

In the practice of takaful in Malaysia, the concept of transparency is applied through its operational system as referred to the Guidelines of Takaful Operational Framework (2013) issued by the Bank Negara Malaysia. The Guideline is formulated based on the principle to promote fairness and transparency to protect the interests of takaful participants. A specific requirement on disclosure and transparency is specified under part 15 of the said Guideline in which it stated:

"15.1 Takaful operators shall be transparent in undertaking activities as part of good governance and to promote better understanding of takaful. Takaful operators are expected to publish details of its operational model together with its underlying Shariah principles, to enable participants, stakeholders and public to better understand the underlying takaful operations. Information provided should be accurate, adequate and up-to-date to enable stakeholders to make an assessment on the takaful operators' financial standing.

15.2 Information disclosed must be made apparent to the participants in documents used at the pre contractual stage, upon signing the contract and throughout the duration of the contract...

15.3 Takaful operators must ensure consistency in information being disclosed in different documents...To further promote transparency, takaful operators should publish on their website, details of products, fees and charges.

15.4 Where takaful operator makes modifications or changes to its operational model or to the terms and conditions of the products, participants should be sufficiently informed of the changes and the impact of the changes..."

(Guidelines of Takaful Operational Framework, 2013)

In addition, under the Guiding Principles on Governance for Takaful (Islamic Insurance)
Undertakings (2009) issued by the Islamic Financial Services Board (IFSB), the takaful operators shall adopt and implement procedures for appropriate disclosures that provide takaful participants with fair access to material and relevant information. Appropriate disclosures of information are required to be made to all stakeholders in order to contribute to a wellfunctioning information environment that shall lead to a good governance practice and thus helps to safeguard the integrity of takaful undertakings, as well as guiding potential takaful participants in their decisions on whether or not to participate in a takaful scheme (Islamic Financial Services Board (IFSB), 2009).

In regards to the protections of property as encourage and permit by the Shariah, specifically for construction works is sought out by the Clients and Contractors through Contractor's All Risks (CAR) Takaful certificates that is meant to provide protections and indemnification against loss and/or damages to contract and temporary works, materials, plants and liability for property damages and bodily injury to third parties (Ahmad Mazlan Zulkifli et. al., 2012). Takaful refers to the concept of Islamic insurance that embraces the elements of mutual protection and shared responsibility to protect participants against unexpected risks or property loss and/ or damages as to the context of construction (Rodziah Ahmad \& Zairol Azhar Auzzir, 2012; Ahmad Mazlan Zulkifli et. al., 2012). The elements of mutual protection, intention and shared responsibility are encouraged in Islam; Allah the Almighty mentiones,

"O you who have believed, do not violate the rites of Allah or [the sanctity of] the sacred month or [neglect the marking of] the sacrificial animals and garlanding [them] or [violate the safety of] those coming to the Sacred House seeking bounty from their Lord and [His] approval. But when you come out of ihram, then [you may] hunt. And do not let the hatred of a people for having obstructed you from alMasjid al-Haram lead you to transgress. And cooperate in righteousness and piety, but do 
not cooperate in sin and aggression. And fear Allah; indeed, Allah is severe in penalty."

(Qur'an Surah Al-Maidah 5:2)

The principles of takaful are based on mutual cooperation (ta' 'awun) and donation (tabaru') (Rodziah Ahmad \& Zairol Azhar Auzzir, 2012; Nasser Yassin \& Jamil Ramly, 2011; Mohd Ma'sum Billah, 2007). These principles are applied when a group of people that is the takaful participants agree between themselves to share the risks of predictable losses and damages to any of the group participants by collecting a sum of money in a form of donations, which when is necessary will be used to compensate and reimburse the losses and damages suffered by any participant of the takaful scheme (Puteri Nur Farah Naadia Mohd Fauzi \& Khairuddin Abdul Rashid, 2013). Upon any occurrence of loss and/or damages to the works insured as specified in a CAR Takaful certificate, the Contractor as takaful participant shall submits a claim to takaful operator for compensation or reimbursement that he is entitled and liable as accordance to the certificate.

\section{Transparency in the Assessment of Claims for Construction Works Loss \& Damage}

A takaful claim is the notification by participant to a takaful operator that payment of an amount or called as reimbursement or compensation is entitled upon any occurrence under the terms of a takaful certificate (Syed Othman Alhabshi et. al., 2012; Engku Rabiah Adawiah Engku Ali \& Odierno, H.S.P., 2008). The objective of reimbursement or compensation of loss and damage is to provide a fair-estimated cost in order to place the participant back to the participant's same financial position immediately before the loss and damage (Takaful Ikhlas Sdn. Bhd., 2014). In order to avoid any fraudulent and excessive claim, a takaful operator is required to manage and process a claim with good, fair and just manners (Rodziah Ahmad \& Zairol Azhar Auzzir, 2012). In addition, the application of good ethics in managing and processing claims will help to boost the public's confidence in the integrity and competence of the professional activities of takaful operator (Puteri Nur Farah Naadia Mohd Fauzi \& Khairuddin Abdul Rashid, 2014; Chamber of Insurance Damages, 2009).

Indeed, it is believed that the settlement of claims would be conducted with fairness and just within a reasonable period of time that lead to an adequate and accurate compensation upon any claims made by a takaful participant (Puteri Nur Farah Naadia Mohd Fauzi \& Khairuddin Abd Rashid, 2013). Thus, to ensure the efficiency in the settlement of takaful claims and make certain of that the takaful participants' rights are duly honoured, the takaful operators among themselves are strongly encouraged have to set and implement an internal appropriate standard and prudent administration guideline of claims management (Ahmad Mazlan Zulkiffi et. al., 2012; Mohd Fadzli Yusof et. al., 2011; Central Bank of Malaysia, 2007). The takaful claims process generally involves five (5) basic procedures as shown in figure 1.

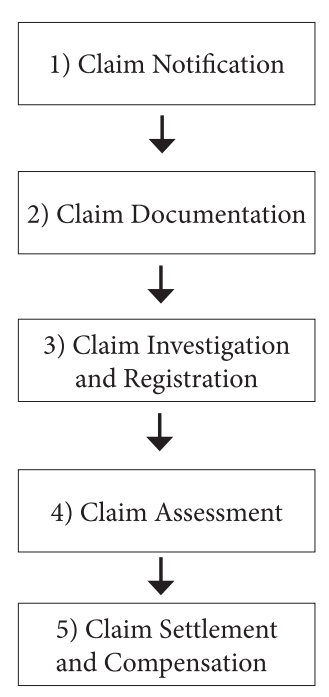

Figure 1: Five (5) basic procedures in handling takaful claims

Generally, the five (5) basic procedures illustrates in figure 1, are applied as basic processes in handling takaful claims for construction works loss and damage under the insurance of works in Contractor's All Risks (CAR) Takaful as well. However, there are some additional specific steps and particular documents that are required to be submitted by the takaful participant in 
particular to construction works loss and damage (Syarikat Takaful Malaysia Sdn. Bhd., 2014). For instance, upon any occurrence of unexpected event that caused loss and damage to construction works and give rise to a claim, the contractor as the takaful participant is required to make a report to the authority body i.e. police immediately before notify the takaful operator (Puteri Nur Farah Naadia Mohd Fauzi \& Khairuddin Abdul Rashid, 2014). Contractor as the takaful participant is also required to submit supporting documents such as letter of award, Bill of Quantities (BQ), evidences of loss and damage and details for claim amount to enable the takaful operator to expedite the claim and carry out the survey (Puteri Nur Farah Naadia Mohd Fauzi \& Khairuddin Abdul Rashid, 2014). Syarikat Takaful Malaysia Sdn. Bhd. (2014) has issued a claim guide handbook for nonmotor that provides details requirements in the investigation of claims under the insurance of works for CAR Takaful that include (see table $1)$.

Table 1: Details requirements in the investigation of claims under the insurance of works for CAR Takaful (Syarikat Takaful Malaysia Sdn. Bhd., 2014)

\begin{tabular}{|c|c|}
\hline Items & Descriptions \\
\hline $\begin{array}{c}\text { Circumstances of loss } \\
\text { and damage }\end{array}$ & $\begin{array}{l}\text { a. Date and time of the incident } \\
\text { b. Details of the responsible parties } \\
\text { c. Nature and extent of loss and } \\
\text { damage } \\
\text { d. Estimated loss and damage }\end{array}$ \\
\hline $\begin{array}{l}\text { The duly completed } \\
\text { and signed form of } \\
\text { claim }\end{array}$ & $\begin{array}{l}\text { a. Technical report before and after the } \\
\text { loss and damage } \\
\text { b. A copy of authorities reports } \\
\text { c. Repair/Replacement estimates } \\
\text { d. Photographs depicting the extent of } \\
\text { loss and damage sustained by the items } \\
\text { claimed } \\
\text { e. A copy of Bill of Quantities (BQ) } \\
\text { and Letter of Award } \\
\text { f. Consultants' reports on extent of loss } \\
\text { and damage } \\
\text { g. Suggested scope of repairs } \\
\text { h. Records detailing the description } \\
\text { and quantity of materials delivered } \\
\text { to site } \\
\text { i. Schedule of work detailing the status } \\
\text { of work done prior to the loss and } \\
\text { damage }\end{array}$ \\
\hline
\end{tabular}

The assessment of the construction works loss and damage claim is conducted by the experts or loss adjusters appointed by the takaful operator. A loss adjuster is an independent party appointed by either takaful operator or participant to conduct investigation and negotiation of settlement of claims arising under Takaful certificate that lead to a reimbursement or compensation of loss and damage that is entitled for participant under a takaful certificate (Ahmad Mazlan Zulkifli et. al., 2012; Islamic Financial Services Board (IFSB), 2009). A loss adjuster will provide a full report on the construction loss and damage claim including the quantum of loss and damage to the takaful operator based on the survey, valuation and estimation carried out.

In addition, the valuation and estimation of losses and damages will be asissted by construction team members such as architect, engineer and quantity surveyor. Following with the report submission by a loss adjuster, the takaful operator is required to prepare a claim settlement offer to the contractor for acceptance. While the claim being investigate, contractor as the takaful participant is obliged to conduct the duty of good faith and ethics to minimize the loss and damage occurred (Puteri Nur Farah Naadia Mohd Fauzi \& Khairuddin Abdul Rashid, 2014; Ahmad Mazlan Zulkifli et al., 2012). For instant, in the event of a construction building is collapsed, the contractor shall take reasonable steps and precautions to safeguard the construction site from further loss and damage.

Moreover, direct assessible guidelines for industry practice in assessing claims are not available freely to the public or takaful participants and operators (Puteri Nur Farah Naadia Mohd Fauzi \& Khairuddin Abdul Rashid, 2013a; 2013b). The Central Bank of Malaysia has issued the Guideline on Claims Settlement Practices (2007), which is intended to improve the intelligibility of the claim estimation and reimbursement process, the guideline merely highlights and focuses on 
the processes and procedures of assessments of claims (part 4.3) and settlement (part 4.4). However, the specific assessment methods in assessing claims for construction works loss and damage in takaful are not further elaborated and provided. Indeed, part 4.3.1 of the Guideline states that the assessment of claims is based on the appointed licensed adjuster's expertise and internal practice.

"4.3 Assessment of Claims; 4.3.1 Within seven working days from the date of receipt of the completed claim form and all relevant supporting documents, appoint licensed/inhouse staff adjusters. A licensed adjuster provides independent professional assessment of the loss giving rise to a claim and ensures fair compensation to claimants; ..."

Critically, public generally and contractors and clients in particular have raised out concern on the lack of transparency and the apparent absence of clear methodology on the way in which claims for compensation for construction works loss and damage were assessed (Travis, 2014; Central Bank of Ireland, 2013). The deficiency in terms disclosures of information and methods in assessing claims especially for construction works loss and damage is involved in the practice of takaful as well as insurance (Doug Macamara \& Banff Executive Leadership Inc., 2014; Travis, 2014). Rupert Travis, Head of Global Construction and Chief Executive of Cunningham Lindsey International Ltd a loss adjusting company mentioned in the Construction Insights that "Greater transparency, more trust and clearer guidance will benefit both insurers and insured".

Based on shared experienced of insurers and policyholders, there is a lack of disclosure of information in assessing claims that shall lead to disputes and uncertainties on the possible outcomes of the settlement of claims (Travis, 2014). Travis (2014) also mentioned that comments are received from insureds as quoted,
"Claims take too long to settle, insurers lack transparency and don't communicate enough with us. We feel insurers sometimes deliberately take an adversarial stance. Claims handlers don't always understand our business and there is a lack of co-operation between co-insurers."

On the other hand, Travis (2014) stated that insurers have different views and commented,

"Customers take too long to provide us with information or notify us of claims. They often hold unrealistic expectations about what is recoverable, give artificial arguments to recover non-recoverable costs and ask us to pay for poor workmanship."

The application of the concepts of disclosures and transparency are emphasized mainly on the practice of account and financial standing and reporting for both insurance and takaful practice in Malaysia. Refer to the Financial Reporting for Takaful Operators (2013) and Financial Reporting (Insurance) (2013) issued by the Bank Negara Malaysia, the minimum disclosure of information requirements set up to be complied by takaful operators with the following key principles:

i) Information should be timely and up-to-date, to avoid undue delays in disclosure which may affect the relevance of the information being disclosed; ii)The scope and content of information disclosed and the level of disaggregation and detail should be sufficient to provide comprehensive, meaningful and relevant information; iii) Adequate disclosures should be provided on areas of uncertainty, in particular information on key estimates and if sensitivity analysis is used, a discussion on the assumptions and the probabilities of the occurrence of various scenarios; and iv) Disclosures should allow comparisons over time and between takaful operators/institutions. 


\section{Methodology}

Part 1: Establishment of Understanding on the concept of transparency in CAR Takaful claims This study is conducted through extensive review on literature pertaining the concept of transparency in which claims for loss and damage for construction works were assessed based on examination of documents available for the researcher through web-based search. The documents used for review on the principles and criteria of transparency practice are the Islamic Financial Services Act (IFSA) (2013) and guidelines in regards to the assessment of claims in takaful issued by the Bank Negara Malaysia as the takaful regulator in Malaysia that are 1) Guidelines of Claims Settlement (2007) and 2) Guidelines of Takaful Operational Framework (2013). Based on the examination of the documents, the principles of transparency in the practice of assessment of claims for loss and damage in construction takaful were established.

Part 2: Assessment from the perspectives of the Contractors and Clients, on whether the dealings in CAR Takaful claims are considered transparent or otherwise

The data collected in part 1 are brought to discussions with ten (10) numbers of experts in a series of individual semi-structured interview. The interview aimed to obtain experts' opinions and agreement on the transparency and disclosures issues in assessing claims for construction works loss and damage. Focusing on obtaining opinions and agreement on the lack of transparency in CAR Takaful claims, it can only be judged and viewed by respondents with wise knowledge and experience of the specific area. Therefore, the targeted respondents shall at least have qualification and possess necessary knowledge, expertise or experience in one (1) of the identified areas (see table 2):
Table 2: Targeted Respondents

\begin{tabular}{|l|l|}
\hline $\begin{array}{l}\text { Identified } \\
\text { Specific Areas }\end{array}$ & Targeted Respondents \\
\hline Takaful Regulator & $\begin{array}{l}\text { Licensed Loss Adjusters by the Central Bank } \\
\text { of Malaysia }\end{array}$ \\
\hline Shariah experts & $\begin{array}{l}\text { Panel of Shariah Advisory Council (SAC) of } \\
\text { the Central Bank of Malaysia }\end{array}$ \\
\hline \multirow{2}{*}{ Takaful Operators } & $\begin{array}{l}\text { Licensed Takaful Operators by the Central } \\
\text { Bank of Malaysia }\end{array}$ \\
\hline \multirow{2}{*}{ Construction } & $\begin{array}{l}\text { Consultants (Architect, Engineer, Quantity } \\
\text { Surveyor) }\end{array}$ \\
\cline { 2 - 2 } & Contractors (CIDB Registration G6 \& G7) \\
\hline
\end{tabular}

Only ten (10) out of the forty-seven (47) targeted respondents invited accepted and available to be interviewed. The questions asked in the interview session concern on the application and adequacy of transparency and accountability in the practice of claims assessment. The ten (10) respondents were asked on the followings: i.) Question 1: Availability and accessibility of information on the processes in assessing claims for CAR Takaful to participants and public; ii.)Question 2: Adequacy and accuracy of information made known to participants i.e. sufficiency of information provided to participants and whether the sufficient information been updated or manageable to the participants;iii.) Question 3: Availability of standard practice or industry practice as regular basis in making assessment for Car Takaful claims; and iv.) Question 4: Ability of loss adjusters or takaful operators to provide explanation and feedback on how CAR Takaful claims were assessed to participant.

\section{Results and Discussion}

Table 3 shows the results of the interviews discussion in frequency table and percentage. Based on the interview conducted, all opinions and views by the respondents are considered appropriate and accepted and reported therein. 
Table 3: Results of the interviews discussion

\begin{tabular}{|c|c|c|c|c|c|}
\hline \multirow{2}{*}{ No. } & \multirow{2}{*}{ Questions } & \multicolumn{2}{|c|}{ Frequency } & \multicolumn{2}{c|}{ Percentage } \\
\cline { 3 - 6 } & & $\begin{array}{c}\text { Totally } \\
\text { Agree }\end{array}$ & Disagree & $\begin{array}{c}\text { Totally } \\
\text { Agree }\end{array}$ & Disagree \\
\hline 1. & Question 1 & 10 & 0 & $100 \%$ & $0 \%$ \\
\hline 2. & Question 2 & 10 & 0 & $100 \%$ & $0 \%$ \\
\hline 3. & Question 3 & 10 & 0 & $100 \%$ & $0 \%$ \\
\hline 4. & Question 4 & 10 & 0 & $100 \%$ & $0 \%$ \\
\hline
\end{tabular}

All ten (10) respondents agreed on dearth of transparency and disclosures of information related to the processes of assessment of CAR Takaful claims. Indeed, it is contended that the lack of transparency is not merely in the practice of takaful alone but also in insurance. Focusing on the adequacy and accuracy of information, all ten (10) respondents conceded that the adequacy of information available and accessible for participants and public are critical. They also called for the operations and system of takaful as Shariah compliant insurance must comply endto-end of Shariah requirements and concepts.

Moreover, all ten (10) respondents agreed that there is poor disclosure of information especially on the clear methodology in which CAR Takaful claims were assessed to participants. One more visible that experts that conducted the assessment of loss refuse to disclose or expose on exact methods in assessing claims simply because they do not prefer to have arguments and disputes where participant may contest on the quantum or validation of the certificate. Furthermore, the rigorous processes and procedures in assessing claims for CAR Takaful are not been exposed to the participant or public in order to protect the operators and eliminate manipulations by participants.

In terms of Shariah legality and requirements based on the dalil presented, the respondents who are experts in Shariah knowledge areas agreed that the concept of transparency and disclosures of information in the assessment of claims CAR Takaful are compulsory and obliged to be applied and the dalil presented to support the argument is appropriate and accepted. Indeed, if the process cannot be explained to participant, thus the practice is considered contravene with the principle of Wayl ul-lil mutaffifin (Woe to those who give less [than due]), because the function of the takaful operator is to make sure that participant fully understand on the principles and aware of the operations of takaful claims for any damages or loss.

\section{Conclusion and Recommendation}

This paper reported on a study on transparency in the assessment of takaful claims for construction works loss \& damage. The outcomes of the study revealed that there is lack of transparency and disclosure of information not merely in the assessment of claims and dealings for CAR Takaful but in conventional insurance as well. It is suggested that transparency is a concern because 1) clear processes and procedures in assessing claims for construction works loss and damage are not being made known to the participants of such products in general and in particular to the areas concerning Shariah requirements based on the Qur'an; 2) in particular to the manner in which claims are valued and compensation decided, takaful operators failed to provide clear explanations on the processes and procedures in conducting claims assessment for construction works loss and damage and 3) indeed such information was also not even being made know or disclose to the takaful operators themselves. Based on the findings of this study, it is also revealed that the current practice of assessment of claims is merely based on internal customary or ad-hoc reports by the loss adjusters, hence support on the event why takaful operators were unable to provide clear and extensive explanations on the processes and procedures in conducting claims assessment for CAR Takaful.

Therefore, it is believed that the takaful and construction industry in Malaysia need swifter action dealings with claims to give participants and public more confidence with greater ownership of the claims handling 
process and decision-making by both takaful participants and operators. Thus, further studies to construct and develop a clear guideline as the basis parameter to be observed by experts or loss adjusters in conducting assessment of claims for CAR Takaful in Malaysia would be a significant voluntary step to enhance the takaful penetration especially in the Malaysian construction industry.

\section{Acknowledgements}

This research is funded by the Ministry of Education Malaysia and the International Islamic University Malaysia (IIUM) to carry out a three-year $\mathrm{PhD}$ programme of research on takaful for construction under the supervision of the second author (ref no: KPT(BS) 860907565086; IIUM/202/C/1/1/AT272).

\section{References}

Qur'an. (2000). ('Abdullah Yusuf 'Ali, Trans.) Kuala Lumpur, Malaysia: Saba Islamic Media Sdn. Bhd.

Ahmad Mazlan Zulkifli, Badrul Hisham Abd. Rahman, Nasser Yassin, \& Jamil Ramly. (2012). Basic Takaful Practices: Entry Level for Practitioners. Kuala Lumpur, Malaysia: Islamic Banking \& Finance Institute Malaysia (IBFIM).

Ahmad Sekreter. (2013). Importance of Transparency in Islamic Finance. Journal of Business , 47-50.

Ainulashikin Marzuki \& Nor Haziah Hashim. (2007). Penetrating the Takaful Market. In A. S. Suhaila Abdul Hamid, Readings in Islamic Financial Services. Kuala Lumpur: Islamic University College Malaysia.

Bryman, A. (2008). Social Research Methods (3rd ed.). New York: Oxford University Press.

Central Bank of Ireland. (2013, October 24).

Central Bank publishes findings from the
Household Property Claims themed inspection. Retrieved on May 9, 2014, from Central Bank of Ireland

Central Bank of Malaysia. (2013, June 28). Financial Reporting for Takaful Operators. Retrieved June 20, 2014, from BNM Guidelines \& Circulars: www.bnm.gov.my

Central Bank of Malaysia. (2013, June 28). Financial Reporting. Retrieved June 20, 2014, from BNM Guidelines \& Circulars: www.bnm. gov.my

Central Bank of Malaysia. (2013, June 26). Guidelines of Takaful Operational Framework. Retrieved January 10, 2014, from BNM Guidelines \& Circulars: www.bnm.gov.my

Central Bank of Malaysia. (2007, September 18). Guidelines of Claims Settlement. Retrieved June 19, 2013, from BNM Guidelines \& Circulars: www.bnm.gov.my

Department of Islamic Development Malaysia (JAKIM). (1972). Insurance. Retrieved October 21, 2014. http://www.e-fatwa.gov.my/fatwakebangsaan/insurans-0

Department of Islamic Development Malaysia (JAKIM). (2009). Conventional Insurance Law to Promote Products by Shariah Perspective. Retrieved October 21, 2014. http://www.e-fatwa.gov.my/fatwa-kebangsaan/ hukum-mempromosikan-produk-insuranskonvensional-menurut-perspektif-syariah

Doug Macamara \& Banff Executive Leadership Inc. (2014). Leadership Acumen. Retrieved May 21, 2014, from Transparency-Exactly what do you mean?: www.banffexeclead.com

Engku Rabiah Adawiah Engku Ali \& Odierno, H.S.P. (2008). Essential Guide to Takaful (Islamic Insurance). Kuala Lumpur, Malaysia: CERT Publications Sdn. Bhd.

Flynn, L. (2014, February 27). Transparency 
in Construction Contracts. Retrieved May 21, 2014, from http://www.fhould.com/ukeurope/articles/transparency-constructioncontracts/\#sthash.7CUBRDR3.pdf

International Shari'ah Research Academy for Islamic Finance (ISRA). (2012). Islamic Financial Syatem: Principles \& Operations. (A. W. Dusuki, Ed.) Kuala Lumpur, Malaysia: Pearson Custom Publishing.

\section{Islamic Financial Services Act (2013)}

Islamic Financial Services Board (IFSB). (2009). Guiding Principles on Governance for Takaful (Islamic Insurance) Undertakings. Islamic Financial Services Board (IFSB).

Islamic Financial Services Board (IFSB) \& International Association of Insurance Supervisors (IAIS). (2006). Regulation and Supervision of Takaful (Islamic Insurance). Kuala Lumpur, Malaysia: Islamic Financial Services Board (IFSB).

Jaggar, D., Ross, A., Love, P. E., \& Smith, J. (2001). Overcoming information opacity in construction: A commentary. Logistics Information Management.

Mikaliu, A., \& Maishanu, M. M. (2014, April 3). Islamic Value System, Accountability and Transparency in the Public Service. Retrieved May 21, 2014, from https://www. academia.edu/2570307/ISLAMIC_VALUE_ SYSTEM ACCOUNTABILITY AND TRANSPĀRENCY_IN_THE_PÜBLIC SERVICE

Mohd Fadzli Yusof, Wan Zamri Wan Ismail, \& Abdul Khudus Mohd Naim. (2011). Fundamentals of Takaful. Kuala Lumpur, Malaysia: Islamic Banking \& Finance Institute Malaysia (IBFIM).

Mohd Ma'sum Billah. (2007). Applied Takaful Modern Insurance (3rd ed.). Petaling Jaya, Selangor, Malaysia: Sweet and Maxwell Asia.
Mohd Shukri Salleh. (2010). Insurance \& Takaful Handbook. Kuala Lumpur, Malaysia: Institut Bank-Bank Malaysia.

Muhammad Iqbal. (2005). General Takaful Practice Technical Approach To Eliminate Gharar (uncertainty), Maisir (gambling), Riba' (usury). Jakarta, Indonesia: Gema Insani.

Muhammad Shabbir. (2010). Adequacy of Disclosure in Islamic Financial Institutions. Retrieved May 21, 2014, from Institute of Islamic Banking \& Insurance (IIBF): http:// www.islamic-banking.com/iarticle_5.aspx

Nasser Yassin, \& Jamil Ramly. (2011). Takaful: A Study Guide. Kuala Lumpur, Malaysia: Islamic Banking and Finance Institute Malaysia (IBFIM).

Puteri Nur Farah Naadia Mohd Fauzi, \& Khairuddin Abdul Rashid. (2014). The Methods in Assessing Takaful Claims for Construction Works Loss and Their Legitimacy from the Shariah Perspectives. The 2nd IIUM-KYOTO University Research Colloquium. Kuala Lumpur: Department of Quantity Surveying \& Procurement and Project Delivery System Research Unit, Kuliyyah of Architecture \& Environmental Design, International Islamic University Malaysia (IIUM) in colloboration with Graduate School of Management, Kyoto University, Japan.

Puteri Nur Farah Naadia Mohd Fauzi., \& Khairuddin Abd Rashid. (2013a). The Procedures and Methods of Assessment of Construction Works Loss for Takaful in Malaysia. Management in Construction

Researchers' Association (MiCRA). Kuala Lumpur: International Islamic University Malaysia (IIUM).

Puteri Nur Farah Naadia Mohd Fauzi., \& Khairuddin Abdul Rashid. (2013b). Takaful: Its Understanding And Application By The Malaysian Contractors In The Construction Industry. First World Congress On Islamicisation 
And Integration Of Human Acquired Knowledge (FWCII 2013). Kuala Lumpur: International Islamic University Malaysia (IIUM).

Puteri Nur Farah Naadia Mohd Fauzi., \& Khairuddin Abd Rashid. (2012). The Understanding Of Takaful Among The Contractors Of The Malaysian Construction Industry. Management in Construction Research Association (MiCRA) Postgraduate Conference. Kuala Lumpur.

Rodziah Ahmad, \& Zairol Azhar Auzzir. (2012). Takaful. Kuala Lumpur, Malaysia: Pearson Malaysia Sdn. Bhd.

Rusni Hassan. (2012). Islamic Banking and Takaful (2nd ed.). Petaling Jaya, Selangor Darul Ehsan, Malaysia: Pearson Malaysia Sdn Bhd.

Sahih Muslim, Book No. 10: The Book of Transactions (Kitab Al-Buyu'), Hadith No. 3661

Said Sami Al Hallaq. (2009). Islamic Insurance In Practice: Modes, Size and Structure in Selected Markets. In A.-R. Y. Ahmed, Principles of Takaful (pp. 115-151). Kuala Lumpur, Malaysia: Islamic Banking Financial Institute Malaysia (IBFIM).

Syed Othman Alhabshi., Kamaruddin Sharif., Shaikh Hamzah Abdul Razak., \& Ezamshah Ismail. (2012). Takaful: Realities and Challenges. Petaling Jaya, Selangor Darul Ehsan, Malaysia: Pearson Malaysia Sdn. Bhd.

Sturges, P. (2007). What is this absence called transparency? The International Centre for Innovation in Education (ICIE) Conference. Pretoria: The International Centre for Innovation in Education (ICIE).

Syarikat Takaful Malaysia Sdn. Bhd. (2014). Download Centre. Retrieved June 10, 2014, from Takaful Malaysia: http://www.takafulmalaysia.com.my/others/Pages/download.aspx.
Takaful Ikhlas Sdn. Bhd. (2014). Certificate terms. Retrieved June 10, 2014, from Takaful Ikhlas: http://www.takaful-ikhlas.com.my/ GUI/pdf/downloads/certificate terms/Fire Certificate_Eng.pdf

Transparency Accountability Initiative. (2014). What is transparency? Retrieved May 21, 2014, from Transparency Accountability Initiative: http://www.transparency-initiative.org/about/ definitions

Tranparency International: The Global Coaliation Against Corruption. (2014). Preventing Corruption on Construction Projects. Retrieved May 21, 2014, from http://archieve. tranparency.org/tools/contracting/construction projects

Travis, R. (2014, March). Improving the Way Claims are Settled. Construction Insights: Challenges and Trends in the Construction Industry , pp. 18-19.

UK Anti-Corruption Forum. (2008). Transparency in Public Sector Construction Projects. UK Anti-Corruption Forum.

Zuriah Abdul Rahman., \& Hendon Redzuan. (2009). Takaful: The 21st Century Insurance Innovation. Shah Alam, Selangor Darul Ehsan, Malaysia: McGraw-Hill (Malaysia) Sdn. Bhd. 
